\title{
Insulin effect during a Heatsynch protocol in dairy cows
}

\author{
Andressa Stein Maffi ${ }^{1}$ (D) Cássio Cassal Brauner ${ }^{2 *}$ (D) Lais Fernanda Mielke ${ }^{1}$ Marcio Erpen Lima ${ }^{3}$ \\ Eduardo Gularte Xavier $^{3}$ Francisco Augusto Burkert Del Pino $^{1}$ (D) Marcio Nunes Corrêa ${ }^{3}$ (i)
}

\begin{abstract}
'Programa de Pós-graduação em Zootecnia, Departamento de Zootecnia, Núcleo de Pesquisa Ensino e Extensão em Pecuária (NUPEEC), Faculdade de Agronomia Eliseu Maciel, Universidade Federal de Pelotas (UFPel), Pelotas, RS, Brasil.

${ }^{2}$ Departamento de Zootecnia, Núcleo de Pesquisa Ensino e Extensão em Pecuária (NUPEEC), Universidade Federal de Pelotas (UFPel), 96010900, Pelotas, RS, Brasil. E-mail: cassiocb@gmail.com. *Corresponding author.

3Programa de Pós-graduação em Veterinária, Núcleo de Pesquisa Ensino e Extensão em Pecuária (NUPEEC), Faculdade de Veterinária, Universidade Federal de Pelotas (UFPel), Pelotas, RS, Brasil.
\end{abstract}

ABSTRACT: The objective of this study was to evaluate the effect of exogenous insulin administration on follicular growth, estrus presentation and conception rate during a protocol of ovulation synchronization. Dairy cows were subjected to the Heatsynch protocol, with the insertion of an intravaginal device containing $1.9 \mathrm{~g}$ of progesterone (CIDR) and an intramuscular injection containing $2.5 \mathrm{mg}$ of GnRH on day 0 . On day 7, the CIDR was removed and subjects were given $12.5 \mathrm{mg}$ of dinoprost. Also on day 7, Insulin Group (IG, $n=21)$ animals received a subcutaneous injection containing $0.25 \mathrm{IU} / \mathrm{kg}$ of recombinant human insulin and the control group (CG, $n=25)$ received a $0.9 \% \mathrm{NaCl}$ injection. On day 8, an injection of $0.5 \mathrm{mg}$ of estradiol cypionate was administered to all cows. Animals were inseminated 12 hours after estrus presentation or at day 10 at fixed time. Follicular development was evaluated on days 7, 9, and 10 using transrectal ultrasonography, estrus presentation was observed between days 8 and 10, and conception rate was evaluated 30 days after AI. There were no differences in growth rate, follicular diameter, estrus presentation, and conception rate. Therefore, application of a single dose of insulin does not promoted an increase in follicular size, estrus presentation and conception rate in dairy cows.

Key words: dairy cow, insulin, ovarian follicle, reproduction.

Efeito da insulina durante um protocolo Heatsynch em vacas leiteiras

RESUMO: O objetivo deste estudo foi avaliar o efeito da administração exógena de insulina sobre crescimento folicular, apresentação de cio e taxa de concepção durante um protocolo de sincronização da ovulação. As vacas holandês lactantes foram submetidas ao protocolo Heatsynch, com inserção do dispositivo intravaginal contendo $1,9 \mathrm{~g}$ de progesterona (CIDR) no dia 0 e uma injeção intramuscular de 2,5 mg de GnRH. No dia 7, o CIDR foi removido e foi aplicado 12,5 $\mathrm{mg}$ de dinoprost. Ainda no dia 7, os animais do Grupo Insulina (IG, $n=$ 21) receberam uma injeção subcutânea de $0,25 \mathrm{UI} / \mathrm{kg}$ de insulina humana recombinante e o grupo controle $(C G, n=25)$ recebeu uma injeção de $\mathrm{NaCl} \mathrm{0,9 \%}$. No dia 8 foi aplicado $0,5 \mathrm{mg}$ de cipionato de estradiol em todas as vacas. Animais foram inseminados 12 horas após a apresentação de cio ou no dia 10 em tempo fixo. O desenvolvimento folicular foi avaliado nos dias 7, 9 e 10 por ultrassonografia transretal, a apresentação de cio foi observada entre os dias 8 e 10 e a taxa de prenhez/IA foi avaliada 30 dias após a IA. Não houve diferença quanto a taxa de crescimento e diâmetro folicular, apresentação de cio e taxa de concepção. A aplicação de uma dose única de insulina não promove o incremento no tamanho folicular, apresentação de cio e taxa de prenhez/IA em vacas de leite.

Palavras-chave: vaca leiteira, folículo ovariano, insulina, reprodução.

\section{INTRODUCTION}

Follicular diameter and estrus presentation during timed artificial insemination (TAI) protocols are factors associated with conception (VASCONCELOS et al., 2001; PERRY et al., 2005; PERRY et al., 2007). Smaller ovulatory follicles generate smaller corpus luteum in the subsequent estrous phase and secrete less progesterone than larger follicles (VASCONCELOS et al., 2001). Inducing ovulation of small follicles may result in low pregnancy rate (VASCONCELOS et al., 2001; PERRY et al., 2005) and increased embryonic mortality rate (PERRY et al., 2005).

Follicular development occurs through the signaling and interaction of gonadotrophins and metabolites (BEAM \& BUTLER, 1999; KAWASHIMA et al., 2012). Follicule-stimulating hormone (FSH) stimulates granulosa cells to develop receptors for insulin, insulin-like growth factor (IGF-I) and growth hormone, whilst IGF-I and insulin supply hormonal stimulation for the 
complete development of the preovulatory follicle and for ovulation (BUTLER, 1999; KAWASHIMA et al., 2007; SHIMIZU et al., 2008; KAWASHIMA et al., 2012). Insulin is a hormone secreted by pancreatic $\beta$-cells and it plays a vital role in the body, signaling energy status to the central nervous system (INGVARTSEN \& ANDERSEN, 2000). In vitro studies have shown that insulin directly stimulates both mitosis and steroid production in cultured bovine granulosa (GUTIERREZ et al., 1997; GLISTER et al., 2001 ), theca (STEWART et al., 1995) and luteal cells (MAMLUK et al., 1999). Together with IGF-I, it stimulates the lutenizing hormone (LH) peak (BEAM \& BUTLER, 1999) and low plasma insulin and IGF-1 concentrations may be linked to LH pulsatility failures (BROWN et al., 2012). Despite the considerable effects of insulin on reproduction, there are still few studies evaluating its role on animals. SIMPSON et al. (1994) observed a larger diameter of follicles in Bos indicus cattle treated with insulin during superovulation protocol. In a study conducted in Angus cattle, administering both insulin and eCG during the TAI protocol lead to an increase in pregnancy rate in cows with a body condition score (BCS) of less than 2.5 (on a scale of 1 to 5 ) in comparison to animals receiving only eCG (SCHNEIDER et al., 2010). In dairy cows, insulin administered alongside glucose promotes increased levels of estradiol and IGF-I (BUTLER et al. 2004).

Therefore, the working hypothesis was that exogenous insulin administration during the TAI protocol would promote greater development of the dominant follicle, estrus presentation, and improve rate for pregnancy per $\mathrm{AI}(\mathrm{P} / \mathrm{AI})$. The objective of this study was to evaluate the effect of exogenous insulin administration during Heatsynch protocol in lactating dairy cows on follicular growth, estrus presentation, and rate for pregnancy per AI.

\section{MATERIALS AND METHODS}

All data collection and procedures in this experiment were approved by the Ethics Committee in Animal Experimentation from the Universidade Federal de Pelotas (Pelotas, RS, Brazil). The study was conducted on a commercial dairy farm in the southern Rio Grande do Sul, (32 $\left.{ }^{\circ} 16^{\prime} \mathrm{S}, 52^{\circ} 32^{\prime}\right)$. Forty-six multiparous and lactating dairy cows, between three and six lactations were kept in a semi-extensive dairy system, in which cows were milked twice daily and are fed with a total mixed ration (TMR) immediately after milking (target $65 \%$ TMR and $35 \%$ grazing pasture). Cows were kept in a pasture of ryegrass during the day (from 0900 to 1700) with water available ad libitum. Average days in milk (DIM) was $84 \pm 14$ days, average daily milk production was $28.33 \pm 1.4 \mathrm{~kg}$, and BCS averaged 2.5 $\pm 0,07$ (range 1-5). All animals were subjected to Heatsynch ovulation synchronization protocol, which consisted of insertion of an intravaginal device $\left(\mathrm{CIDR}^{\circledR}\right.$ - Zoetis, São Paulo, Brazil) containing $1.9 \mathrm{~g}$ of progesterone, and application of $2.5 \mathrm{mg} \mathrm{GnRH}$, i.m, Gestran ${ }^{\circledR}$ Plus (Tecnopec, São Paulo, Brazil) on day 0 (D0). On day 7 (D7), CIDR was removed and cows received $12.5 \mathrm{mg}$ dinoprost - i.m., $5 \mathrm{mg}$ / $\mathrm{mL}^{-1}$ - Lutalyse ${ }^{\circledR}$ (Zoetis, São Paulo, Brazil). Also on D7, cows were divided into two groups: an Insulin Group (IG, $\mathrm{n}=21)$ and a control group (CG, $\mathrm{n}=25)$. The Insulin Group received a subcutaneous injection containing $0.25 \mathrm{IU} / \mathrm{kg}$ of human insulin, Novolin N (Novo Nordisk, Bagsvaerd, Denmark), and the control group received a subcutaneous injection containing $1 \mathrm{ml}$ of $\mathrm{NaCl}(0.9 \%)$. On day 8 (D8) all animals received an injection containing $1 \mathrm{mg}$ of estradiol cypionate - i.m., $2 \mathrm{mg} / \mathrm{mL}$, E.C.P (Zoetis, São Paulo, Brazil). Estrus detection was completed daily between D8 and day 10 (D10) for approximately two hours in the morning and in the evening by trained technicians. Cows that showed estrus signs were then artificially inseminated 12 hours after detection. Cows that showed no estrus signs were inseminated at a fixed time on day D10. Pregnancy diagnosis was performed 30 days after insemination using transrectal ultrasonography. Evaluation of follicular diameter was completed on days 7, 9 and 10 using transrectal ultrasound (5-0-MHz, Weld 3000, B-mode; Welld Medical Electronics Company Ltd. Shenzhen, China).

Blood was sampled prior to insulin injection on day 7 to evaluate endogenous insulin level. Samples were then centrifuged at $1.500 \mathrm{rpm}$ for 15 minutes, and the resulting serum was transferred into ependorfs and frozen at $-80^{\circ} \mathrm{C}$ until hormonal analysis. Insulin concentrations were quantified by a commercial ELISA assay according to BEITINGER et al (2012) (Ins-EASIA ${ }^{\circledR}$, DIASource, Louvain-LaNeuve, Belgium), with a minimum detection limit of $1.13 \mathrm{IU} / \mathrm{mL}$ using a plate reader (Thermo Plate $^{\circledR}$, TP Reader, São Paulo, SP, Brazil).

Data were analyzed by considering treatment (i.e. insulin vs. control groups) as a fixed factor against response variables of follicular size and follicular growth, this was evaluated using a one-way ANOVA and repeated measures. Binomially distributed data, such as estrus detection and rate for pregnancy per AI, were analyzed using chi-square 
tests. Pearson correlation was used to evaluate the correlation of BCS, follicular diameter and estrus presentation with the pregnancy rate. The statistical software NCSS (2005) was used to analyze all data.

\section{RESULTS AND DISCUSSION}

Insulin treatment on day 7 did not increase the daily growth rate daily growth rate, and the follicular diameter of the preovulatory follicle (Table 1). The rate of estrus presentation between groups did not differ (CG: $56.3 \%$; IG 43.5\%, $p=0.55$ ). The overall rate for $\mathrm{P} / \mathrm{AI}$ did not differ between groups $(p$ $=0.84$ ), with rates of $23.50 \%$ for $\mathrm{CG}$ and $26,30 \%$ for IG. In addition, the pregnancy rate was not influenced by the presentation of estrus or not $(p=0.28)$. When we evaluated the correlation coefficients of pregnancy rate with $\mathrm{BCS}$, follicular diameter at day 10 of the protocol, estrus presentation and insulin levels, these factors had a low correlation (Table 2).

Insulin levels at day 7 of the protocol, prior to treatment application, indicated that animals in both groups had similar metabolic conditions $(\mathrm{CG}=25.8 \pm 2.4 \mathrm{ng} / \mathrm{mL} ; \mathrm{IG}=27.5 \pm 2.4 \mathrm{ng} / \mathrm{mL}$; $p=0.81)$. Despite considerable milk production $( \pm 28 \mathrm{~kg} /$ day $)$, high insulin levels were reported in cows from both groups; and therefore, could be related to the days in milk (DIM) of the animals. The recent postpartum is marked by severe negative energy balance (NEB), because output energy via milk production exceeds energy intake via feed via consumption (KAWASHIMA et al., 2012). The first week postpartum is characterized by reduction levels of glucose, insulin, IGF-I and LH, with NEB nadir during the first or second week postpartum (BUTLER \& SMITH, 1989), adversely affecting reproduction. From the 3 weeks postpartum a balance between the lactation curve and the dry matter intake was performed, reducing the NEB.

Since its discovery by BANTING et al (1922), insulin has been described as a key signal for energy homeostasis. Insulin maintains peripheral glucose homeostasis through the stimulation of glucose uptake, oxidation, and storage (DONATO et al., 2012). In the reproductive system, studies have demonstrated its complex roles in ovarian function, such as regulation of ovarian steroidogenesis, follicular development, and proliferation of granulosa cells (ADASHI et al., 1997; PORETSKY et al., 1999). In vitro studies demonstrated an improvement in granulosa cells proliferation and estradiol production. In this way, the authors expected an improvement in the estrus and in the follicular phase. In addition, low levels of IGF-I and perhaps insulin, reduced follicular responsiveness to gonadotrophic stimuli, causing low production of estradiol by the dominant follicle and affecting LH pulsatility (BUTLER, 1999). Despite this, there remain few studies conducted in vivo with the aim of understanding if this metabolic hormone is able to facilitate reproduction when used exogenously. The use of insulin in beef cattle during the protocol of superovulation causes an increase in the diameter of large follicles $(8 \mathrm{~mm})$ and an increase in estradiol production (SIMPSON et al., 1994). In a study conducted by Butler (2004) in dairy cows, insulin infusion associated with glucose for 96 hours raised estradiol production after 30 hours. Similarly, administering insulin to goats before or during a

Table 1 - Follicular size and growth rate in multiparous Holstein cows treated with $0.25 \mathrm{IU} / \mathrm{kg}$ of human insulin, Novolin $\mathrm{N}(\mathrm{IG}, \mathrm{n}=21)$ or $\mathrm{NaCl}(0,9 \%)(\mathrm{CG}, \mathrm{n}=25)$ during Heatsynch protocol.

\begin{tabular}{lccc}
\hline Measurements & CG & IG & P P value \\
\hline Follicular size D7 (mm) & $11.83 \pm 0.86$ & $11.68 \pm 0.91$ & 0.98 \\
Follicular size D9 $(\mathrm{mm})$ & $14.41 \pm 0.88$ & $14.72 \pm 0.86$ & 0.98 \\
Follicular size D10 (mm) & $15.12 \pm 0.91$ & $15.62 \pm 1.05$ & 0.98 \\
Follicular growth D7-D9 (mm) & $2.94 \pm 0.0 .32$ & $3.41 \pm 0.0 .32$ \\
Follicular growth D9-D10 (mm) & $1.28 \pm 0.42$ & $1.87 \pm 0.49$ & 0.30 \\
Follicular growth D7-D10 (mm) & $3.96 \pm 0.57$ & $5.29 \pm 0.66$ & 0.14 \\
Heat rate (\%) & 56.3 & 23.5 & 0.55 \\
Overall for pregnancy per AI rate (\%) & 26.3 & 20.0 \\
\hline Pregnancy per AI rate IATF (\%) & 14.3 & 28.6 \\
\hline Pregnancy per AI rate with observation heat (\%) & 36.4 & 0.84 \\
\hline
\end{tabular}


Table 2 - Correlation coefficients between BCS, heat and follicular diameter with Pregnancy.

\begin{tabular}{lcccc}
\hline Measurements & \multicolumn{2}{c}{----Pregnancy--- } & \multicolumn{2}{c}{------ P------- } \\
\hline & CG & IG & CG & IG \\
BCS (R2) & -0.10 & -0.06 & 0.69 & 0.80 \\
Heat (R2) & -0.24 & -0.09 & 0.33 & 0.70 \\
$\begin{array}{l}\text { Follicle diameter } \\
\text { (D10) (R2) }\end{array}$ & 0.004 & -0.37 & 0.98 & 0.22 \\
Insulin (R2) & -0.15 & -0.07 & 0.79 & 0.61 \\
\hline
\end{tabular}

superovulation protocol, results in an increase in estradiol production (SELVARAJU et al., 2003). In the study of Landau (2000), an increase in insulin levels prior to estrus presentation was observed.

From the results of our study and other related research, the beneficial effects of using insulin exogenously can be summarized by two main points, the first relating to the increased performance of insulin when the animals are in metabolically challenging conditions. A study previously carried out by our group on beef cows (SCHNEIDER et al., 2010) supports this, as exogenous insulin administered during the TAI protocol increased conception rate only in animals with a body condition below 2.5 and without temporary weaning. Therefore, it can be postulated that insulin may be more effective in higher produce cows or in early DIM cows, once those animals face a challenge metabolic situation.

The second point is that insulin, when associated with reproductive hormones, seems to promote increased follicular growth in cattle (BHATIA \& PRICE, 2001; GUPTA et al., 2010; SCHNEIDER et al., 2010; CHAVES et al., 2012). In vitro study showed that the addition of high doses of insulin $(100 \mathrm{ng} / \mathrm{ml})$ to culture media of granulosa cells is able to stimulate aromatase activity, even in the absence of FSH (BHATIA \& PRICE, 2001). However, this same effect is observed with low doses of insulin $(10 \mathrm{ng} / \mathrm{ml})$ and FSH $(1 \mathrm{ng} / \mathrm{ml})$ when they are administered together (BHATIA \& PRICE, 2001). These hormones appear to have complementary actions. For example, SHIMIZU et al. (2008) demonstrated that the addition of FSH to preovulatory follicle cultures promotes greater expression of insulin receptors. Moreover, studies in vivo using insulin alongside FSH, showed that this combination promoted the growth of larger follicles and the estradiol production (SIMPSON et al., 1994). Additionally, in cows with $\mathrm{BCS} \leq 2.5$, administering insulin together with eCG lead to an improvement in pregnancy rate when compared to animals that received only eCG (SCHNEIDER et al., 2010). In anestrus buffaloes, the use of GnRH-associated insulin had positive effects on ovarian activity, estrus presentation and ovulation rate (GUPTA et al., 2010). In conclusion, a single dose of exogenous insulin administration during Heatsynch protocol does not improve follicular growth, estrus presentation or pregnancy rate in lactating dairy cows.

\section{ACKNOWLEDGEMENTS}

To the Núcleo de Pesquisa, Ensino e Extensão em Pecuária (NUPEEC) and Granjas 4 Irmãos S.A. for providing theanimals and farm facilities. To the Conselho Nacional de Desenvolvimento Científico e Tecnológico (CNPq) for financial support (MCTIC/CNPq N¹4/2013). And, this study was financed in part by the Coordenação de Aperfeiçoamento de Pessoal de Nível Superior (CAPES), Brasil - Finance code 001.

\section{BIOETHICS AND \\ BIOSECURITY \\ COMMITTEE APROVAL}

Protocol no 23110.002358/2013-58

\section{DECLARATION OF CONFLICT OF INTERESTS}

The authors declare no conflict of interest. The founding sponsors had no role in the design of the study; in the collection, analyses, or interpretation of data; in the writing of the manuscript, and in the decision to publish the results.

\section{AUTHORS' CONTRIBUTIONS}

The authors contributed equally to the manuscript.

\section{REFERENCES}

ADASHI, E. Y. et al. The mouse intraovarian insulin-like growth factor I system: departures from the rat paradigm. Endocrinology, v.138, p.3881-3890, 1997. Available from: Available from: $<$ https://www.ncbi.nlm.nih.gov/pubmed/9275078>. Accessed: Nov. 01, 2018. doi: 10.1210/endo.138.9.5363.

BANTING, F. G., et al. Pancreatic extracts in the treatment of diabetes mellitus. Canadian Medical Association Journal, v.12, p.141-146. 751, 1922. Available from: Available from: <https:// www.ncbi.nlm.nih.gov/pmc/articles/PMC1524425/>. Accessed: Nov. 01,2018

BEAM, S. W.; W. R. BUTLER. Effects of energy balance on follicular development and first ovulation in postpartum dairy cows. Journal of Reproduction Fertility Supplement, v.54, p.411-24, 1999. Available from: Available from: <http://www. ncbi.nlm.nih.gov/pubmed/10692872>. Accessed: Mar. 10, 2018.

BHATIA, B.; C. A. PRICE. Insulin alters the effects of follicle stimulating hormone on aromatase in bovine granulosa cells in vitro. Steroids, v.66, p.511-519, 2001. Available from: <Available from: https://www.ncbi.nlm.nih.gov/pubmed/11182140. Accessed: Mar. 10, 2018. doi: 10.1016/S0039-128X(00)00218-X.

BEITINGER, P. A, et al. 2012. Glucose tolerance in patients with narcolepsy. Sleep, 35:231-236. Available from: Available from: $<$ https://www.ncbi.nlm.nih.gov/pubmed/22294813. Accessed: Mar. 10, 2018. doi: 10.5665/sleep.1628. 
BROWN, K. L., et al. Hormones, metabolites, and reproduction in Holsteins, Jerseys, and their crosses. Journal dairy science, v.95, p.698-707, 2012. Available from: Available from: <https: https:// www.ncbi.nlm.nih.gov/pubmed/22281334>. Accessed: Mar. 10, 2018. doi:10.3168/jds.2011-4666.

BUTLER, W. R. Effects of energy balance on folicular development and first ovulation in postpartum dairy cows. Journal of reproduction and fertility, v. 54, p. 411-24, 1999 Available from: <Available from: https://www.ncbi.nlm.nih.gov/ pubmed/10692872>. Accessed: Nov. 01, 2018.

BUTLER, W.R. \& SMITH, R.D. Interrelation ships between energy balance and postpartum reproductive function in dairy cattle. Journal of dairy science, v.72. p.767-783, 1989. Available from: $<$ https://www.ncbi.nlm.nih.gov/pubmed/2654227>. Accessed: Feb. 05, 2018. doi: 10.3168/jds.S0022-0302(89)79169-4.

CHAVES, R. N., et al. The effects of insulin and folliclesimulating hormone (FSH) during in vitro development of ovarian goat preantral follicles and the relative mRNA expression for insulin and FSH receptors and cytochrome P450 aromatase in cultured follicles. Biology Reproduction, v.87, n.3, p.69, 2012. Available from: <Available from: <http://www.ncbi.nlm.nih. gov/pubmed/22811569>. Accessed: Mar. 01, 2018. doi: 10.1095/ biolreprod.112.099010.

DONATO, J. The central nervous system as a promising target to treat diabetes mellitus. Current Topics in Medicinal Chemistry, v. 12, p.2070-2081, 2012. Available from: <Available from: https://www. ncbi.nlm.nih.gov/pubmed/23167796>. Accessed: Nov. 01, 2018.

GLISTER, C., et al. Interaction between follicle-stimulating hormone and growth factors in modulating secretion of steroids and inhibin-related peptides by nonluteinized bovine granulosa cells. Biology of Reproduction, v.65, p.1020-1028, 2001 Available from: <Available from: https://www.ncbi.nlm.nih. gov/pubmed/11566722>. Accessed: Feb. 05, 2018 doi: 10.1095/ biolreprod65.4.1020

GUPTA, V., et al. Effect of pretreatment with insulin on ovarian and fertility response in true anestrous buffaloes to gonadotrophinreleasing hormone. Buffalo Bulletin, v.29, p.172-179, 2010. Available from: Available from: <http://ibic.lib.ku.ac.th/ebulletin/2010-172.pdf>. Accessed: Feb. 05, 2018.

GUTIERREZ, C. G., et al. The recruitment of ovarian follicles is enhanced by increased dietary intake in heifers. Journal of Animal Science, v.75, n.7, p.1876-84, 1997. Available from: Available from: <http://www.ncbi.nlm.nih.gov/pubmed/9222845>. Accessed: Feb. 10, 2018 doi:: 10.2527/1997.7571876x.

INGVARTSEN, K. L.; J. B. ANDERSEN. Integration of metabolism and intake regulation: a review focusing on periparturient animals. Journal dairy science, v.83, p.173-1597, 2000. Available from: Available from: $<$ https://www.ncbi.nlm.nih. gov/pubmed/10908064. Accessed: Fev. 5, 2018. doi: 10.3168/jds. S0022-0302(00)75029-6.

KAWASHIMA, C., et al. Relationship between metabolic hormones and ovulation of dominant follicle during the first follicular wave post-partum in high-producing dairy cows. Reproduction, v.133, p.155-163, 2007. Available from: Available from: $<\mathrm{https}$ ://www. ncbi.nlm.nih.gov/pubmed/17244742. Accessed: Fev. 10, 2018. doi: 10.1530/REP-06-0046.

KAWASHIMA, C., et al. Nutritional factors that regulate ovulation of the dominant follicle during the first follicular wave postpartum in high-producing dairy cows. Journal Reproduction Development, v.58, n.1, p.10-16, 2012. Available from: <http:// www.ncbi.nlm.nih.gov/pubmed/22450279>. Accessed: Fev. 10, 2018. doi: $10.1262 /$ jrd.11-139N

MAMLUK, R., et al. Hormonal regulation of messenger ribonucleic acid expression for steroidogenic factor-1, steroidogenic acute regulatory protein, and cytochrome P450 sidechain cleavage in bovine luteal cells. Biology of Reproduction, v.60, p.628-634, 1999. Available from: <https://www.ncbi.nlm.nih. gov/pubmed/10026109>. Accessed: Fev. 10, 2018. doi: 10.1095/ biolreprod60.3.628.

PERRY, G. A., et al. Relationship between follicle size at insemination and pregnancy success. Proceedings of the National Academy of Sciences, v.102, p.5268-5273, 2005. Available from: $<$ https://www.ncbi.nlm.nih.gov/pubmed/15795381>. Accessed: Fev. 10, 2018. doi: 10.1073/pnas.0501700102.

PERRY, G. A., et al. Relationship between size of the ovulatory follicle and pregnancy success in beef heifers. Journal of animal science, v.85, p.685-689, 2007. Available from: <https://www. ncbi.nlm.nih.gov/pubmed/17060416>. Accessed: Fev. 10, 2018. doi: $10.2527 /$ jas.2006-519.

PORETSKY, L. et al. The insulin-related ovarian regulatory system in health and disease. Endocrine Reviews, v.20, p.532582, 1999. Available from: Available from: <https://www.ncbi. nlm.nih.gov/pubmed/10453357>. Accessed: Nov. 01, 2018. doi: 10.1210/edrv.20.4.0374

SCHNEIDER, A., et al. The use of insulin to improve fertility of timed inseminatedpostpartum suckled beef cows. Pesquisa agropecuária brasileira, v.45, p.1219-1221, 2010. Available from: <Available from: http://www.scielo.br/scielo.php?script=sci arttext\&pid=S0100-204X2010001000023. Accessed: Feb. 05, 2018. doi: 10.1590/S0100-204X2010001000023.

SHIMIZU, T., et al. Involvement of insulin and growth hormone (GH) during follicular development in the bovine ovary. Animal Reproduction Science, v.106, n.1-2, p.143-52, 2008. Available from: <Available from: <http://www.ncbi.nlm.nih.gov/ pubmed/17507188>. Accessed: Feb. 05, 2018. doi: 10.1016/j. anireprosci.2007.04.005.

SIMPSON, R. B., et al. Effect of exogenous insulin on plasma and follicular insulin-like growth factor I, insulin-like growth factor binding protein activity, follicular oestradiol and progesterone, and follicular growth in superovulated Angus and Brahman cows. Journal of Reproduction and Fertility, v.102, n.2, p.483-92, 1994. Available from: <Available from: <http://www.ncbi.nlm.nih. gov/pubmed/7532225>. Accessed: Feb. 15, 2018. doi: 10.1530/ jrf.0.1020483.

STEWART, R. E., et al. Effects of insulin-like growth factor I and insulin on proliferation and on basal and luteinizing hormoneinduced steroidogenesis of bovine thecal cells: involvement of glucose and receptors for insulin-like growth factor I and luteinizing hormone. Journal of Animal Science, v.73, p.37193731, 1995. Available from: Available from: <https://www.ncbi. nlm.nih.gov/pubmed/8655449>. Accessed: Feb. 15, 2018. doi: $10.2527 / 1995.73123719 x$.

VASCONCELOS, J. L., et al. Reduction in size of the ovulatory follicle reduces subsequent luteal size and pregnancy rate. Theriogenology, v.56, n.2, p.307-14, 2001. Available from: Available from: <http://www.ncbi.nlm.nih.gov/ pubmed/11480622>. Accessed: Feb. 15, 2018. doi: 10.1016/ S0093-691X(01)00565-9.

Ciência Rural, v.49, n.8, 2019. 